this seems appropriate. Other requests for benzodiazepines are refused. We commend this policy to other doctors caring for drug misusers in general practice.

FRANCES M MOLEY General practitioner MARY DAWKES Community drug team liaison drug counsello JONATHAN P BERRY General practitioner

Boundary House Medical Practice,

Sale, Manchester M33 2RH

1 Strang J, Griffiths P, Abbey J, Gossop M. Survey of injected benzodiazepines among drug users in Britain. BMf 1994;308: 1082. (23 April.)

2 British National Formulary No 27. London: BMA, Pharmaceutical Press, 1994:137.

3 Ruben S, Morrison C. Temazepam misuse in a group of injecting drug users. Br 7 Addict 1992;87:1387-92.

4 Seivewright N, Dougal $w$. Benzodiazepine misuse. Current Opinion in Psychiatry 1992;5:408-11.

5 Ashton $H$. Risks of dependence on benzodiazepine drugs: major problem of long term treatment. $B M F$ 1989;298: 103-4.

\section{Hepatitis C virus infection}

\section{Define seropositivity}

EdrTor,-Carol A Seymour's editorial ${ }^{1}$ and the papers on hepatitis $C$ in the same issue illustrate the problems of defining chronic hepatitis $\mathrm{C}$ and of identifying patients who would benefit from regular follow up in a gastroenterology clinic. We and colleagues have found that only liver biopsy reliably identifies patients with chronic infection. Kate E Ryan and colleagues rightly question the effectiveness of counselling when so little is known of the natural course of this infection. ${ }^{2}$

Liver biopsy is not a minor procedure, and scarce and expensive medical resources should be used only when the patient will benefit. The patient must be given an accurate prognosis and treatment with interferon alfa and other antivirals should be offered when appropriate, although the long term effects of such intervention on the prognosis of liver disease associated with hepatitis $\mathrm{C}$ are unknown.

Much of this information is not new. It has been known since the 1970 s that a normal serum alanine aminotransferase activity in repeated samples taken over an extended period does not exclude the finding of non- $A$, non- $B$ hepatitis on liver biopsy. ${ }^{34}$ Published studies of liver biopsies in blood donors positive for antibodies to hepatitis $\mathrm{C}$ virus show varying proportions with normal histological appearances and different patterns of severity of liver disease.

An accurate definition of what constitutes a specific result of a test for hepatitis $\mathrm{C}$ antibody is essential. We have attempted such a definition based on an algorithm devised for confirmatory testing of repeatedly reactive samples from blood donors. ${ }^{5}$ We found that serum that was reactive in three different enzyme immunoassays had a much greater chance of being reactive in a line immunoassay than serum that was reactive in only one or two enzyme immunoassays. Alternatively, a mean ratio of the absorbance obtained for the sample to the cut off absorbance for these assays of $>3.00$ was associated with a much increased chance of a positive result for viral RNA by the polymerase chain reaction, confirming that strong reactivity by enzyme immunoassay is more likely to be specific. Samples from only two of 172 blood donors with viraemia failed to react in all three enzyme immunoassays; the viruses in these two cases were antigenic variants uncommon in our population of blood donors.

Our definition of a specific result of a test for hepatitis $\mathrm{C}$ antibody is reactivity in three different enzyme immunoassays, with a mean ratio of the absorbance obtained for the sample to the cut off absorbance greater than a minimum derived under standard conditions from a group of people known to be positive, and reactivity in a line immunoassay. This definition excludes serum with low concentrates of specific antibody such as that from patients with resolving infection, who are unlikely to have viraemia or to need medical intervention.

J CRASKE

Consultant virologist

W K PAVER

Clinical scientis

Public Health Laboratory,

Withington Hospital,

Manchester M20 8LR

1 Seymour CA. Asymptomatic infection with hepatitis C virus. BMF 1994;308:670-1. (12 March.)

2 Ryan KE, MacLennan S, Barbara JAJ, Hewitt PE. Follow up of blood donors positive for antibodies to hepatitis $\mathrm{C}$ virus. $B M F$ 1994;308:696-7. (12 March.)

3 Berman M, Alter HJ, Ishak KG, Pucell RH, Jones AE. The chronic sequelae of non-A, non-B hepatitis. Ann Intern Med 1979;91:1-6.

4 Rakella J, Redeker AG. Chronic liver disease after acute non-A non-B viral hepatitis. Gastroenterology 1979;77:1200-2.

5 Craske J, Paver WK, Farmer D. An algorithm for screen reactivity in blood donors in enzyme immunoassays for antibodies to hepatitis C virus. I Immunol Methods 1993;160: 227-35.

\section{Psychosocial impact similar to that of HIV} infection

EDrToR,-Over four fifths of injecting drug users seen by our community drug team are positive for hepatitis $\mathrm{C}$ virus and find coping with the knowledge of this difficult, given the uncertain implications of such a diagnosis. Counselling such clients is difficult as clear guidelines on the epidemiology, infectivity, and prognosis of asymptomatic hepatitis $\mathrm{C}$ are lacking.' We have been concerned recently about instances when patients were denied ordinary care because they were positive for the virus. One of our clients, a former injecting drug user in her 20 s who receives maintenance treatment with low dose methadone, was refused treatment by her dentist after she disclosed to him that she was positive for the virus. On referral to an NHS dental clinic she was placed on a waiting list despite the urgency of her dental condition as she had to be given an appointment at the end of an afternoon so that adequate precautions could be taken.

We agree with Kate E Ryan and colleagues that disclosure of the fact that a patient is positive for hepatitis $C$ virus can have serious psychosocial implications, ${ }^{2}$ which may mimic those associated with positivity for HIV. The issues of counselling people at risk, consent to testing, and confidentiality of results need to be addressed urgently.

JAN NEELEMAN
Senior registrar
CLARE UNWIN
Community charge nurse
MICHAEL FARREL
Consultant

Maudsley Community Drug Team,

London SE5 8AZ

1 Ford C. Asymptomatic hepatitis C infection. BMF 1994;308: 1235. (7 May.)

2 Ryan KE, MacLennan S, Barbara JAJ, Hewitt PE. Follow up of blood donors positive for antibodies to hepatitis $C$ virus. $B M \mathcal{F}$ 1994;308:696-7. (12 March.)

\section{Treatment with interferon reduces} viraemia

EDrToR,-Carol A Seymour's editorial on the management of chronic hepatitis $C^{1}$ has initiated an interesting discussion, with some doctors advocating a policy of no intervention. ${ }^{2}$ Although the natural cause of chronic hepatitis $\mathrm{C}$ is still a matter for debate, at least a fifth of infected patients are likely to develop cirrhosis or a hepatocellular carcinoma, or both. ${ }^{3}$ We still do not know how to identify those patients who are at risk of developing permanent liver damage, but liver function tests are clearly of little value.

Most hepatologists would agree that patients with fibrosis or chronic active hepatitis with bridging necrosis proved by biopsy are probably at high risk of developing cirrhosis (by analogy with chronic hepatitis B). Formal studies to confirm this in hepatitis $\mathrm{C}$, however, have not been published. A liver biopsy therefore provides some information regarding the likely prognosis and, in our view, is essential in patients with abnormal serum transaminase activities.

Identifying patients who are at high risk of developing progressive disease is of value only if we can offer treatment. High dose interferon reduces viraemia to undetectable levels (an analysis with the polymerase chain reaction) in up to a quarter of treated patients. ${ }^{4}$ We do not know whether this represents a permanent cure, but data showing prolonged normalisation of results of liver function tests in these patients indicate that this is probable. Studies combining interferon and oral antiviral agents are under way, and recent results suggest that these new treatment regimens may "cure" $43 \%$ of treated patients ( $\mathrm{L}$ Chemelle et al, VIth international symposium on viral hepatitis, Madrid, 1994). Hence we are in a position to offer patients treatment that may considerably improve their prognosis.

Although there is still legitimate debate regarding the optimal management of patients with chronic hepatitis $\mathrm{C}$, the current discussions should not be used as an argument for therapeutic nihilism: without intervention many patients with this disease will die. In our view Seymour's advice is sound: patients with chronic hepatitis $C$ should be referred to centres skilled in managing this disorder so that they can benefit from the latest management options.

G R FOSTER Lecturer in medicine H C THOMAS

Liver Unit, Professor of medicine

Academic Department of Medicine,

London W2 1NY

1 Seymour CA. Asymptomatic infection with hepatitis C virus. BMF 1994;308:670-1. (12 March.)

2 Valori R, Christie J, Ford C. Asymptomatic hepatitis C infection. $B M$ F 1994;308:1235. (7 May.)

3 Farci P, Purcell RH. Hepatitis C virus: natural history and experimental models. In: Zuckerman AJ, Thomas HC, eds. Viral hepatitis. Edinburgh: Churchill Livingstone, 1993.

4 Shindo M, Di Bisceglie AM, Hoofnagle JH. Long-term followup of patients with chronic hepatitis C treated with alpha
und up of patients with chronic hepatitis
interferon. Hepatology 1992;15:1013-6.

\section{Hepatitis B and medical student admission}

\section{Admission should be based on merit}

EDrToR, $-B M \mathcal{F}$ was right to publish an editorial on hepatitis B and medical student admissions and to lend its authority to the case for screening of students after admission. ${ }^{1}$ The editors contributed the slightly provocative subtitle and amended some of the text after my last sight of it (unwisely in my opinion) in the interests, presumably, of making a more hard hitting message. As a means of engendering controversy where there was room for informed and balanced debate, this has been a journalistic "success" and has elicited a predictably nettled response from Peter Richards and Frank Harries, who are provoked to tilt at the person ("the luxury of opinion without responsibility") and the journal ("irresponsible"), without producing a substantive argument in support of the Committee of Vice-Chancellors and Principals' guidelines. ${ }^{2}$ This contrasts with letters published simultaneously from the BMA medical students 